\title{
Selecting Socio-scientific Issues for Teaching
}

\section{A Grounded Theory Study of How Science Teachers} Collaboratively Design SSI-Based Curricula

\author{
Tamara S. Hancock $^{1}$ (D) Patricia J. Friedrichsen ${ }^{2} \cdot$ Andrew T. Kinslow $^{3} \cdot$ Troy D. Sadler $^{4}$
}

Published online: 31 July 2019

(C) The Author(s) 2019

\begin{abstract}
Currently there is little guidance given to teachers in selecting focal issues for socio-scientific issues (SSI)-based teaching and learning. As a majority of teachers regularly collaborate with other teachers, understanding what factors influence collaborative SSI-based curriculum design is critical. We invited 18 secondary science teachers to participate in a professional development on SSI-based instruction and curriculum design. Through intentional design, we studied how these teachers formed curriculum design teams and how they selected focal issues for SSI-based curriculum units. We developed substantiative grounded theory to explain these processes. Key findings include how teachers' tensions and agential moves worked in tandem in the development of a safe and shared place to share discontentment and generate opportunities to form design teams and select issues. Teacher passion and existing resources are factors as influential as considerations for issue relevance. Implications for teacher professional development and research are included.
\end{abstract}

\section{Introduction}

Advances in science and technology continuously create new intersections of science and society that result in complex and often controversial issues (Janasoff 2004). These areas of intersection, such as biotechnology and climate change (Janasoff 2010), have been identified as socio-scientific issues (SSI) within the science education community (Fleming 1986) and have been positioned as productive contexts for teaching and learning (Zeidler 2014). Science

Tamara S. Hancock

hancockts@missouri.edu

1 College of Veterinary Medicine, University of Missouri, 1600 Rollins Road, Columbia, MO 65211, USA

2 College of Education, University of Missouri, 303 Townsend Hall, Columbia, MO 65211, USA

3 Columbia Public Schools, 1818 W. Worley Street, Columbia, MO 65203, USA

4 School of Education, University of North Carolina at Chapel Hill, CB 3500 Peabody Hall, Chapel Hill, NC 27599, USA 
instruction based on SSI can have a positive impact on student learning of science content (Herman, 2015; Klosterman and Sadler 2010; Lewis and Leach 2006), including the nature of science (Eastwood et al. 2012; Khishfe and Lederman 2006; Sadler et al. 2004; Zeidler et al. 2002), and argumentation and reasoning skills (Romine et al. 2016; Sadler et al. 2007; Zeidler et al. 2013; Zohar and Nemet 2002). Overall, SSI-based instruction has emerged as an effective way for students to contextualize their science learning within a complex social and political context.

In the USA, the Next Generation Science Standards (NGSS) (NGSS Lead States 2013; National Research Council (NRC), 2012), a national policy document, offers a set of science education standards for grades 1-12. These standards consist of 3-dimensional performance expectations, comprised of disciplinary core ideas, science or engineering practices, and crosscutting themes. However, state policymakers are responsible for setting education standards at the state level. Currently, out of 50 states, 20 states have adopted NGSS as their science standards and another 22 have adopted an aligned version of NGSS (https://ngss.nsta.org). Due to state and local community control of education, there is no national science curriculum. As states adopt new science standards, school districts and their teachers must write new curricula aligned with their state's new standards. The present study took place in a Midwestern state that adopted a closely aligned version of NGSS in 2017. As teachers in our state were revising their curricula, we used this window of opportunity to collaborate with them to design NGSSaligned curriculum units using an SSI approach. In other countries, teachers may have more or less control over the design of their curriculum; however, at most local levels, US teachers have flexibility in designing curricula within the limitations of alignment with state standards. Therefore, this study has applications beyond this context to other situations in which teachers are collaborating to design SSI curricula.

SSI curriculum unit design requires careful consideration of the focal SSI to ensure that it features both social and scientific components (Sadler 2011; Zeidler 2014) and that it is complex, relevant, and engaging for students. For example, while the issue of clean water represents a complex issue, the scope of the issue is too large. All students would advocate for clean water. But, when the issue of clean water is narrowed to a particular context (e.g., Flint, Michigan), the social complexities of the issue become apparent, making the issue more relevant and engaging for students. To further problematize the nature of the focal issue, we use the issue of antibiotic resistance. Although the issue has strong social components, students struggle with the target science content, natural selection, as it is difficult for them to distinguish between individual bacteria and populations (Friedrichsen et al. 2016). Additionally, the natural selection story is further complicated by the role of lateral gene transfer, the acquisition of genetic material from another organism without being its offspring, in the spread of antibiotic resistance (Smith et al. 2015). To guide science teachers in designing SSI-based curriculum units, there are several SSI instructional frameworks in the research literature (Marks and Eilks 2009; Presley et al. 2013) and in the practitioner literature (Zeidler and Kahn 2014); however, teachers are offered little guidance in the critical first step of selecting a focal issue. To date, this critical step of SSI focal issue selection has not been problematized in the literature and consequently, we know little about how teachers choose a socio-scientific issue.

As teachers engage in curriculum design, they do not work in isolation. In the USA, $81 \%$ of K-12 teachers report that they regularly collaborate with other teachers (Rotermund et al. 2017); however, little is known about factors that influence collaborative SSI-based curriculum design. Building on teachers' collaborative work environments and best practice 
recommendations that teachers engage in collective practice as part of PD (National Academies of Sciences, Engineering, and Medicine 2015), we invited secondary science teachers to participate in a PD on SSI-based instruction and curriculum design. During the PD, teachers formed curriculum design teams and co-designed SSI-based units to implement in their classrooms. Using grounded theory methods, we studied this collaborative curriculum design process. Specifically, the research questions are as follows: (1) How do teachers form curriculum design teams within a PD workshop? And, (2) how do curriculum design teams select a focal issue for their SSI-based curriculum units? These findings will inform PD that supports teachers' design and implementation of SSI-based curriculum units.

\section{Literature Review}

There is little literature that investigates teachers' collaborative selection of focal issues for SSI-based teaching and learning. As such, the literature review is organized around the following sections: teacher collaboration in general, teachers' collaborative curriculum design, teachers' perspectives on using SSI-based approaches and their practices associated with designing and enacting SSI-based teaching, and criteria for issue selection for SSI-based curriculum. Together, these sections triangulate and illuminate a gap in the literature.

\subsection{Teacher Collaboration in General}

We begin by summarizing two reviews of teacher collaboration at a general level (i.e., Kelchtermans 2006; Vangrieken et al. 2015). Collaboration is defined as "teachers' cooperative actions (their actual doing things together) for job-related purposes" (Kelchtermans 2006, p. 220). According to Kelchtermans' (2006) review, teacher collaboration is mediated by the organizational context of the school as well as the agenda and content of the collaboration. Teachers value collaborations that focus on practical aspects related to student learning or wellbeing. For a collaboration to result in teacher learning, teachers need to first establish a level of trust and safety that eventually allows them to confront their existing beliefs. However, in confronting beliefs, the risk of conflict increases. Vangrieken et al. (2015) reviewed 82 studies of teacher collaboration (2000-2015) and viewed teacher collaboration as occurring on a continuum from a group of individuals to increasing levels of interdependence among individuals. They identified a lack of deep level teacher collaboration, possibly related to teacher isolation, a culture of teacher individualism, and teachers' desire to avoid examination of their underlying beliefs. Vangrieken et al. (2015) reported the benefits of collaboration at the teacher level that include increased teacher motivation, decreased workload, improved morale, reduced isolation, and an increase in student-focused instruction; negative consequences include competitiveness, tensions that lead to conflicts, increased workload, and conformity based on the majority. Collaboration can be hindered if teachers lack necessary skills, are unwilling to collaborate, if confrontations occur, or personalities conflict. Collaboration can be understood in terms of process and outcome. Factors that facilitate collaboration occur primarily at the process level (e.g., defined focus, clear member roles, flexibility); some authors argue that collaboration needs to occur around a common discipline, such as biology or chemistry. Vangrieken et al. (2015) noted that the collaboration literature focuses on reasons for, requirements, and effects of collaboration, but neglects the actual process of collaboration. They called for studies that examine the phenomenon of teacher collaboration. 


\subsection{Collaborative Curriculum Design}

As little research has been conducted regarding teachers' collaborative design of SSI-based curricula, we draw upon a related area, teacher design teams collaboratively designing contextbased curricula. Teachers working collaboratively can design innovative curricula with adequate support, and the design process may lead to teachers with increased skills in contextualizing science concepts for their students (Coenders et al. 2010; de Putter-Smits et al. 2012; Huizinga et al. 2014; Huizinga et al. 2015). It is imperative that curriculum design supports be provided before, during, and after the collaborative design process (Binkhorst et al. 2015; Huizinga et al. 2014; Olin and Ingerman 2016). Exemplary curricula and scoring guides facilitate teacher growth, and PD facilitators should provide them as important supports for teachers (Voogt et al. 2011). Other helpful processes and materials to support the work of curriculum design teams include assessment scoring guides (Coenders et al. 2010), common language guides for acronyms or technical terminology (Huizinga et al. 2014, 2015), and active reflection on the design process (Huizinga et al., 2014).

Clarke and Hollingworth's (2002) Interconnected Model of Professional Growth (IMPG) has been a useful framework for studying teacher learning (i.e., change) within collaborative curriculum design work (Drits-Esser 2015; Voogt et al. 2011; Voogt et al. 2012). The IMPG consists of four interconnected domains in which teachers may experience change: the Personal Domain, consisting of teachers' knowledge, beliefs, and attitudes; the Domain of Practice, consisting of teachers' professional abilities and practice; the Domain of Consequences, comprised of the salient outcomes teachers observe as a result of implementing new practices; and the External Domain, consisting of the external sources of information or stimulus (e.g., the PD). Although the Clarke and Hollingsworth (2002) model was designed to examine individual teacher growth, Voogt and colleagues (Voogt et al. 2011, 2012) used the IMPG to examine change at the group level when teachers were engaged in collaborative curriculum design. They reported that design teams primarily experienced gains in the Personal Domain and Domain of Practice. Furthermore, teachers' enactment of the curriculum, as well as reflection during and after, improved teachers' self-confidence within the Personal Domain (Voogt et al. 2011).

The teachers' Personal Domains, Domains of Practice, and External Domains - i.e., their various contexts - also strongly influence curriculum design and implementation (Davis et al. 2016; Handelzalts 2009; Huizinga et al. 2015; McFadden 2015). Moreover, teachers' roles can change in the process of curriculum design. Wallace and Priestly (2016) described how teachers shifted from purveyors of information to creative designers of contextualized curricula that challenges students in the short-term (i.e., during the lessons), as well as in the long-term (i.e., promoting critical problem solving). All in all, teachers are capable of designing innovative curricula in teams, but require support during the design and implementation phases. Collaborative curriculum design and implementation can support teacher learning, particularly in the areas of Personal Domain and Domain of Practice.

\subsection{Socio-scientific Issues and Teachers}

The SSI literature base has grown extensively over the past 15 years, but most SSI-related studies have focused on various dimensions of student learning (for a review, see Zeidler 2014). Few empirical studies have focused on teachers, their perspectives on using SSI, and practices associated with designing and/or enacting SSI-based teaching. An early investigation 
of secondary science teacher perspectives on using SSI in their classrooms yielded a typology of teacher profiles: (1) teachers who embraced the use of SSI; (2) teachers who saw potential in using issues, but cited constraints that prohibited actively incorporating SSI into their classes; (3) teachers who were ambivalent toward the positioning of SSI in science classrooms and preferred to see SSI addressed in other subject areas; and (4) teachers opposed to the incorporation of SSI in science classes (Sadler et al. 2006). The vast majority of teachers participating in the study were characterized by one of the first two profiles, which indicates that most teachers accepted the premise that SSI could be a useful context for science learning. This pattern was documented with other studies of in-service teachers (Barrett and Nieswandt 2010) as well as preservice teachers (Pedretti et al. 2007). Bosser and colleagues extended this work on teacher perspectives through a longitudinal study of teacher enactment of SSI over the course of a year. The teachers with whom they worked embraced SSI teaching generally, but they identified emergent tensions between the goals of SSI teaching and a focus on science content (Bosser et al. 2015).

Despite the relatively positive perspectives on SSI held by many science teachers, research on teacher views and practices has identified numerous constraints to the successful adoption of SSI teaching. These constraints include teacher perceptions of limited time for both planning and classroom enactment (Ekborg et al. 2013; Sadler et al. 2006), lack of SSI-oriented curricular materials (Lee et al. 2006; Tidemand and Nielsen 2017), and limited support from local administrators (Saunders and Rennie 2013). Explorations of teacher enactment of SSI learning experiences have documented some ways in which teachers struggle when using SSI. These struggles include teacher discomfort with controversial conversations in their classrooms (Bryce and Gray 2004; Day and Bryce 2011), limited assessment practices (Tidemand and Nielsen 2017), and a tendency to focus exclusively on scientific ideas at the expense of contextualized understandings of the issue (Ratcliffe and Millar 2009). However, even with these constraints and challenges, numerous cases have documented ways in which teachers have successfully enacted SSI-oriented teaching (e.g., Lee and Witz 2009; Saunders and Rennie 2013; Simon and Amos 2011). Bosser and colleagues (Bosser et al. 2015) suggested that SSIbased teaching can not only be successfully enacted but also that "integrating SSI is a beneficial way of stimulating the transformation of classroom practices" (p. 174).

\subsection{Socio-scientific Issue Selection}

The SSI literature emphasizes that the selected SSI should be current, controversial, relevant to students, have connections to science content, and allow for open discussion among learners (Hofstein et al. 2011; Kolstø 2001; Levinson 2006; Marks and Eilks 2010; Stolz et al. 2013). Zeidler and Sadler (2008) further elaborated by characterizing SSI as complex, ill-structured authentic problems with undetermined solutions that require moral reasoning and challenge students' normative expectations. Scholars have further refined aspects of SSI, including categorizing types of SSI based on the nature of the science discipline and the degree of human risk involved (Fensham 2012), the controversial aspects of SSI (Levinson 2006), and types of relevancy (Van Aalsvoort 2004). Despite the robust understanding of what SSIs are, little is known about teachers and their issue selection process. In these next sections, we summarize these contributions to our understanding of SSI, because they should inform the issue selection process.

Fensham (2012) proposed a categorization scheme for SSI using the Cynefin Framework (Kurtz and Snowden 2003), based on the certainty of the science and the level of human risk. 
The categories of this framework are simple case, complicated, complex, and chaos. Simple case SSIs are direct applications of established knowledge from a single science discipline, and the associated human risk is zero or very low, e.g., a broken arm. Fensham (2012) estimated that $90 \%$ of science teaching falls into this category. Complicated SSIs involve the application of established knowledge from several science disciplines and the human risk is low to medium, e.g., a heart bypass surgery. Complex SSIs involve uncertain science from multiple disciplines and the human risk is high, e.g., global warming. The fourth category, chaos, involves uncertain science, and the human risk is very high to out of control, e.g., Pacific island nations facing rising sea levels due to global warming. Fensham cautioned that science teachers working individually may not be prepared to teach issues that fit in the categories of complex cases and chaos.

With regard to controversial aspects of SSI, Levinson (2006) reviewed the SSI literature and identified the following characteristics of a controversial issue:

when people start from different premises; hold different key beliefs, understandings, values, or offer conflicting explanations or solutions that are rationally derived from the premises; when it involves a substantial number of people or different groups; and when the issue is not capable of being settled by appeal to evidence. (p. 1204)

Using McLaughlin's (2003) nine categories of disagreement, Levinson illustrated how controversy can range on a continuum based on the role of evidence and social dimensions. For example, at the one end of the continuum, there is insufficient evidence, yet the criteria for the evidence are agreed upon and when evidence is available it should settle stakeholders' differences. At the other end of the continuum, "there is no agreement about whole frameworks of understanding relevant for judgement" (p. 1212) and stakeholders may find "the discourses used are incompatible and uncomprehended by contending parties" (p. 1212).

Relevance of the issue is critical to the success of an SSI unit. It is possible that whereas teachers view an issue as relevant to students, students do not see the same relevance. Indeed, Hofstein et al. (2011) cautioned that relevance is a subjective judgment. Stolz et al. (2013) suggested that an issue is relevant if it affects the current or future lives of students. Van Aalsvoort (2004) identified four different uses of the term relevance in the chemistry education literature: personal relevance, professional relevance, social relevance, and personal/social relevance. Similarly, Stuckey and colleagues (Stuckey et al. 2013) suggested three basic dimensions of relevance: the individual dimension, the societal dimension, and the vocational dimension. Personal or individual relevance refers to making a connection to students' lives, while professional or vocational relevance refers to possible science-related career choices. Social or societal relevance refers to the goal of "clarifying chemistry's purpose in human and social issues" (p. 1152), while personal/social relevance refers to helping students develop into responsible citizens. Sadler (2004) recommended that educators who are seeking to make science more relevant to their students through SSI-based instruction use local issues or alternatively, help students see connections between global issues and themselves.

At a more holistic level of conceptualizing SSI instruction, Marks and Eilks (2009) developed a framework for designing a SSI-based curriculum that included five criteria for selecting a socio-scientific issue: "authenticity, relevance, evaluation undetermined in a socioscientific respect, allows for open discussion, and deals with questions from chemistry and technology" (p. 235). Authenticity is judged by whether or not the selected issue is present in a variety of contemporary media sources. Various stakeholders must have expressed authentic 
differences in opinion within public debates, and the issue must allow for open decisionmaking processes. Specifically, this is the possibility that debate can occur "without harming any of the students by touching too deeply into their ethical or religious values or their socioeconomic status" (Hofstein et al. 2011, p. 1466). Using this conceptual framework, Stolz et al. (2013) collaborated with teachers to operationalize Marks and Eilks' (2009) criteria and developed test statements for each criterion. For example, the criterion of allowing for open discussion can be tested by thought experiments to identify different viewpoints, which are then "checked to make sure that no individuals, religious or ethnic groups would feel insulted or pushed to the fringe of society by their use" (p. 368).

When teachers implement SSI-based curricula, those curricula tend to be designed by researchers (e.g., Eastwood and Sadler 2013; Eilks 2002; Klosterman and Sadler 2010; Peel and Friedrichsen 2018) or generated through close collaboration between researchers and a few teachers to design SSI units, e.g., climate change (Zangori et al. 2017), antibiotic resistance (Friedrichsen et al. 2016), shower gels, and musk fragrances (Marks and Eilks 2010). Although these studies provide important insights on teacher implementation of SSIbased curricula, they shed little light on how teachers grapple with the process of SSI selection. In the practitioner literature, Zeidler and Kahn's (2014) book, It's Debatable!, offers limited guidance on selecting an SSI, offering four key features of SSI units: (1) consideration of a controversial issue with social and scientific connections; (2) deliberation of the moral and ethical dilemmas involved; (3) opportunities for argumentation and discourse; and (4) context for rigorous science content and process skills (p. 46).

\subsection{Summary}

Teachers are capable of designing innovative curricula but require support during the design and implementation phases. Collaborative curriculum design and implementation can support teacher learning, particularly in the areas of Personal Domain and Domain of Practice. The emergent literature on teachers and SSI has focused on teachers' perspectives on SSI, as well as constraints and challenges to implementing SSI-based curriculum. With regard to selecting a SSI, the research literature has articulated the characteristics of the science (e.g., certainty of the science and degree of human risk), a continuum for controversy, and the types of relevancy. What is missing in the literature is how teachers engage in the process of selecting an SSI. If SSI-based instruction is going to be taken up beyond a select, small groups of teachers collaborating closely with researchers, we need a better understanding of the teachers' process of selecting focal issues for SSI-based curriculum.

\section{Theoretical Perspective}

The paradigmatic assumptions and logic associated with symbolic interactionism are foundational to the development of grounded theory (Charmaz 2014). Likewise, many of these assumptions guided our process of substantive theory development grounded in case data. Key assumptions of this theoretical perspective related to our interpretations are briefly summarized.

Symbolic interactionism is a pragmatic and dynamic understanding of the reciprocal nature of interpretation and action. The pragmatic assumptions that underscore this perspective emphasize open-ended processes and change, rather than assumptions of stability and 
continuity. Symbolic interactionism views "human actions as constructing self, situation, and society" (Charmaz 2014, p. 262) and centers the semiotic meanings people make through ongoing interactions with objects, structures, and people in process. Interactions are regarded in the context of their environments, where communication and language produce symbolic and meaningful interpretations. These interpretations affect peoples' views, values, knowledge, and capacity to act (agency) (Benzies and Allen 2001; Charmaz 2014). It is shared meanings, rather than individual ones, that are foundational to the capacity of an individual to engage in agential moves (Benzies and Allen 2001).

The situated actions and interactions of people are the analytical foci of symbolic interactionism. Jeon (2004) implored, "the researcher must be able to actively interact with the persons being researched and see things from their point of view, and in their natural context ... the researcher needs to be actively engaged in the world of the study" (p. 251). We committed ourselves to investigating the coupling of teacher's individual agencies into joint action, as well as an openness to the "developmental course of action" that emerged as we came together, interacted, and developed grounded theory (Denzin 2004).

\section{Context}

The study took place within a PD workshop offered at a major land-grant university located in the Midwest USA. The PD was led by a team of three science education researchers and six graduate students. The first author was a participant observer in the workshop, and the rest of the authors were workshop facilitators. In the following sections, we describe the PD and the teachers who participated.

\subsection{Design of SSI Professional Development}

\subsubsection{SSI Teaching and Learning Framework}

Early in the workshop, we shared the SSI Teaching and Learning (SSI-TL) Framework with the teachers (Friedrichsen et al. 2016; Presley et al. 2013; Sadler et al. 2017). The SSI-TL Framework provides an overview of three sequential phases within an SSI-based curriculum unit (see Fig. 1). In the first phase, students are introduced to a focal issue. In the second phase, the issue becomes a context through which students explore fundamental science concepts and practices aligned with the NGSS, which fosters the development of scientific literacy and identities that allow students to navigate and negotiate complex social issues with substantive connections to science. For students engaged in SSI instruction framed within the SSI-TL, the essential learning outcomes are awareness and understanding of the focal issue, understanding of the NGSS contextualized through the issue, the development of competencies for the NGSS science practices, and the development of socio-scientific reasoning. Socio-scientific reasoning represents the critical thinking and reasoning that students should be able to develop and apply to many different SSI through the SSI-TL (Sadler et al. 2007). In the third phase, SSI-based curriculum units conclude in a culminating experience that provides an opportunity for students to synthesize their ideas, perspectives, and research related to the issue being explored. Further details on using the SSI-TL can be found at our project website: http://ri2. missouri.edu/. In this study, we focus on understanding how teachers select the focal issue used to introduce and frame an SSI-based curriculum unit. 


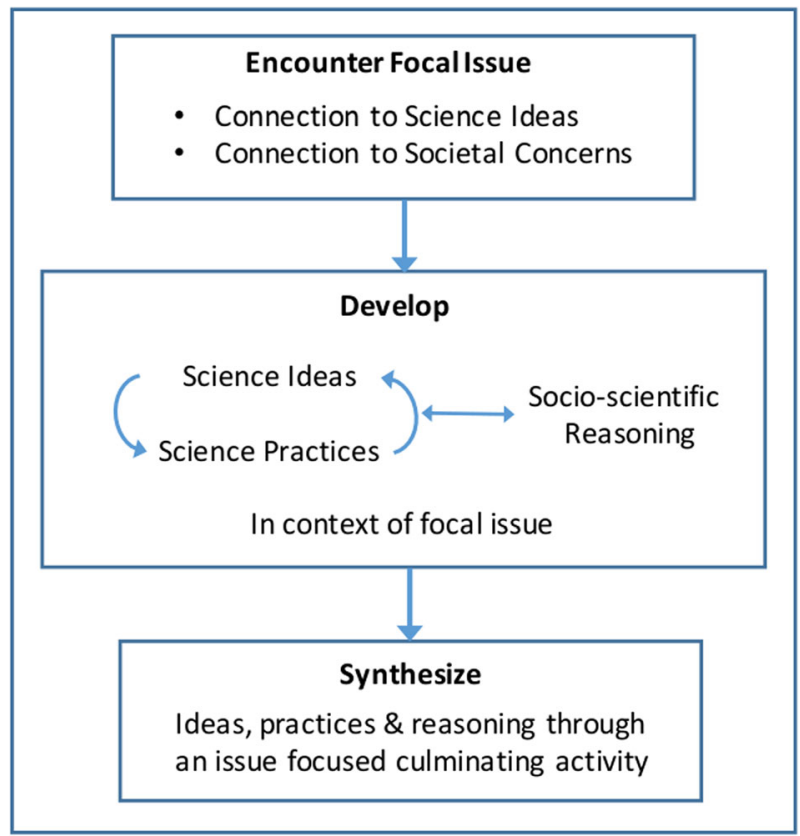

Fig. 1 SSI Teaching and Learning Framework (SSI-TL) used to inform both PD design and teachers' collaborative development of SSI-based units. Reproduced from http://ri2.missouri.edu/ with permission

\subsubsection{Workshop Format}

The 35-h workshop occurred in two sessions - 2 days in early March 2016 and a 3-day session in mid-June 2016. Table 1 shows an overview of the PD activities. The March workshop introduced the SSI-TL (Sadler et al. 2017), sample SSI units, and curriculum unit design resources, which included assessment rubrics, unit and lesson plan templates, and a planning heuristic (http://ri2.missouri.edu/). During this session, the PD facilitators asked the teachers to form curriculum design teams of 2-3 teachers with the goal of co-creating a SSI curriculum unit, which the teachers could each implement in their classrooms during the next school year. To structure formation of teams, the teachers were assigned to large groups based on the courses they taught: chemistry (4 teachers), environmental science ( 5 teachers), biology (6 teachers), and anatomy/physiology (3 teachers). From those content groups, teachers were asked to form smaller design teams of their choosing (2-3 teachers) and select a focal issue for their curriculum unit. To help teachers select an issue, we provided a set of resources, including sample SSI units, a panel discussion of project team members discussing SSI units they had designed, and a series of targeted questions to consider when selecting an issue. Although these resources were made available throughout the PD, they were not prescriptive. Rather, these supports were intentionally designed to facilitate teachers meeting the summative task for the workshop: the development of a SSI-based curriculum unit. Table 2 shows each design team, its members, and the issue they selected.

The June session focused primarily on providing time and space for the design teams to collaboratively develop their SSI-based units. The teachers also participated in workshop breakout sessions on a select set of the NGSS practices, and they further explored sample SSI-based units. All participants completed our summative task for the workshop and 
Table 1 Overview of March and June PD workshop sessions

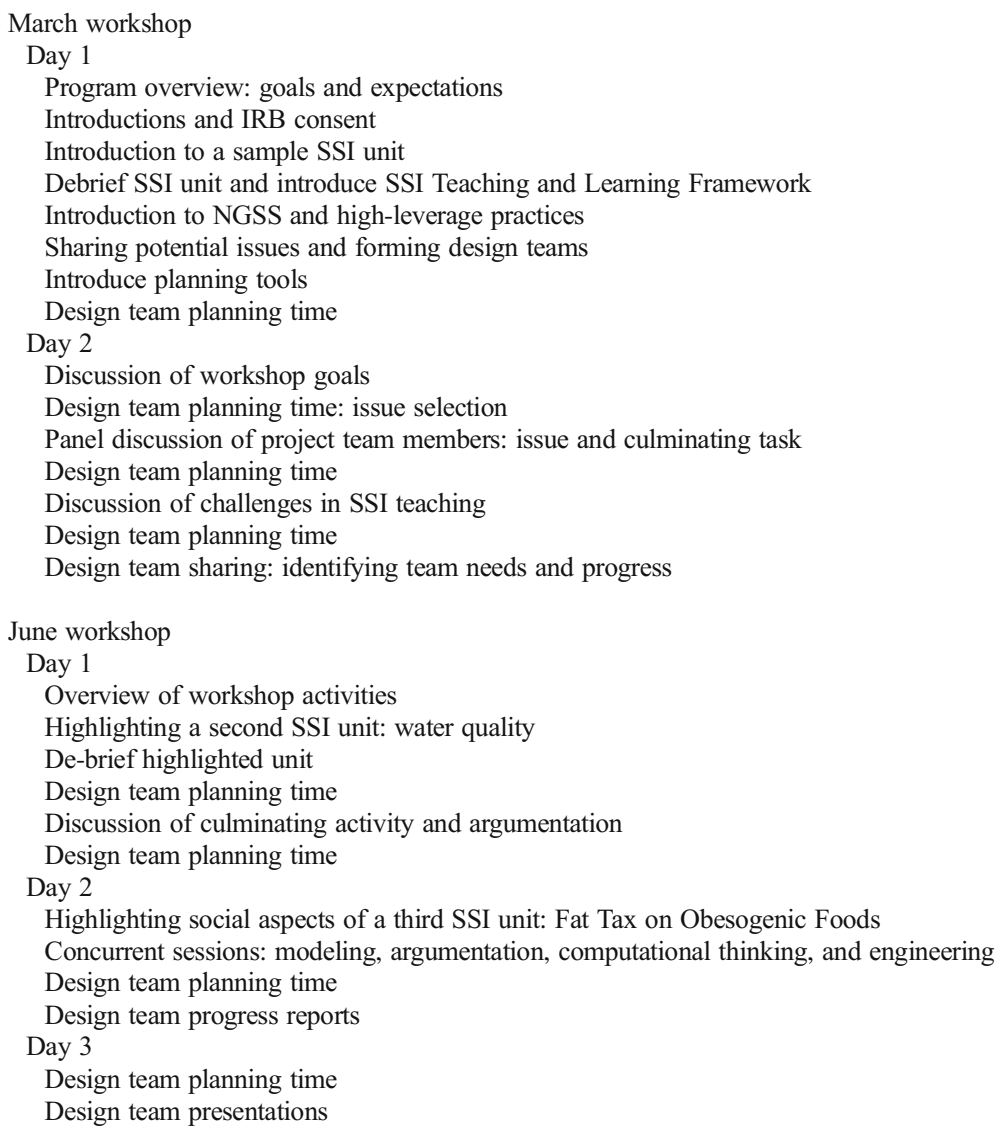

submitted finalized curriculum units by the end of July 2016. The length and scope of the completed full units varied based on each design team's unique situation; however, they typically resulted in 2 to 3 weeks of instruction. Teachers were encouraged, but not required, to implement their curriculum units in the following school year.

Table 2 Design teams and their associated subject area, teachers, and selected socio-scientific issue (SSI)

\begin{tabular}{lll}
\hline Design team & Teachers (pseudonyms) & Selected SSI \\
\hline Anatomy \& Physiology Team & Harry, Margaret, Sherry & $\begin{array}{c}\text { Performance enhancing drug use } \\
\text { in high school athletics } \\
\text { Mars colonization }\end{array}$ \\
Biology Team & Judith, Katherine & Tax on junk food \\
Biology \& Communicative Arts & George, Rebecca & Use of nitrates in food \\
Chemistry Team 1 & Marie, Julia & Clean water \\
Chemistry Team 2 & Jess, Tonya & Invasive plant species \\
Ecology Team & Adam, Jemma & Nuclear power \\
Environmental Science Team $1^{\text {a }}$ & Rose, Marissa, Edward & Flooding in Saint Louis \\
Environmental Science Team $2^{\text {a }}$ & Millie, Suzanne &
\end{tabular}

${ }^{\text {a }}$ Teams comprised of teachers from the same school or district 


\subsubsection{Participants}

We employed purposeful recruitment of participants to best inform our research questions and minimize potential conflicts or attrition from participants (Merriam 1998; Creswell 2014). We identified and invited 30 science teachers who met the following criteria:

1. Currently teaching secondary biology, chemistry, or environmental science in diverse geographic locations throughout our state.

2. Receptive to learning about socio-scientific issue curriculum and instruction design.

3. Demonstrated commitment to teacher learning and professional growth.

Eighteen teachers accepted our invitation to participate in the workshop, and their teaching experience ranged from 1 to 32 years. Seven teachers (39\%) were early-career with 1-5 years teaching experience. Five (28\%) were mid-career participants having taught for 6-10 years. The remaining six (33\%) participants were veteran teachers with 10 or more years of teaching experience. Over half of the participants $(55 \%)$ taught at schools within mid-size towns with populations of 2500-50,000 people, defined as urban clusters by the U.S. Census Bureau (2016). Twenty-eight percent of participants taught in urbanized schools within cities of 50,000 or more people, and $17 \%$ of the teachers worked in rural districts. Quantification of free or reduced lunch (FRL) can be used as a marker of school poverty levels, and participants' schools' FRL ranged from 10.5 to $62.6 \%$ (Department of Elementary and Secondary Education n.d.). The median for the group was $46.1 \%$ FRL. Some teachers taught in the same school building, others taught in the same school district, and a third group of teachers were solo participants from their school district. Teachers received hotel accommodations, per diem, and a stipend for participating in the workshop. All teachers consented to participate in the research study.

\section{Methods}

Our research questions interrogated two processes of people engaging in the co-construction of meaning in specific processes: forming design teams in a PD and then together selecting a focal issue for a SSI curriculum unit. There is sparse literature regarding these processes in tandem - of teacher collaboration and issue selection - which led us to select a method that would focus our analysis on co-constructive processes as informed by symbolic interactionism. Accordingly, we chose to analyze the data using constructivist grounded theory methods (Charmaz 2014) within a case study design (Merriam 1998). Grounded theory, as an analytical method, is well-suited to illuminate processes, such as the processes of how the teachers in the PD formed design teams and selected their issue for their SSI-based unit. Since the case is bounded by participants in the workshop, our theory is substantive rather than formal. A substantive theory is developed for a specific area of inquiry while a formal theory is developed for a conceptual area of inquiry and generalizable (Glaser and Strauss 1967).

Grounded theory is the inductive "discovering of theory from data systematically obtained from social research" (Glaser and Strauss 1967, p.2). Strauss and Corbin (1994, 1998) refined the methodology, describing grounded theory as a "set of well-developed categories that are systematically interrelated through statements of relationship to form a theoretical framework that explains some relevant social, psychological, educational, nursing or other phenomenon" 
(1998, p. 22). Charmaz (2014) built on this foundational work to further articulate analytical strategies for developing grounded theory, and her work informed our data analysis. Grounded theory analysis employs a constant comparative process to the data and the theory under development, where constant comparative analysis is the ongoing cross-checking of analytic products, in addition to creating and revising new qualitative codes and emergent, interpretive themes. Charmaz (2014) cautioned against using grounded theory methods for the purpose of developing a descriptive case study. To address this, we regularly met and questioned our analysis, revisited data, and openly questioned each other in order to ensure a strong grounded theory analysis extended beyond the scope of a descriptive case study.

\subsection{Data Sources}

Data sources included field notes and semi-structured interview transcripts. Field notes were taken by multiple researchers observing and/or participating in the workshop sessions. We conducted semi-structured interviews with each design team near the end of the June workshop; these design team interviews are denoted as Team Interview. A semi-structured protocol was used because this data collection was for a larger research project; however, those questions that provided insight into team dynamics and how the team self-described their issue selection process were more narrative in nature. Follow-up individual interviews, noted as Interview, occurred after the June workshop. Each interview approximated $1 \mathrm{~h}$ in length, providing space for personal reflection and discussion of individual perspectives (Creswell 2014). Because of the case study design, data was produced within the bounded case, rather than to a point of saturation.

\subsection{Data Analysis}

The first three authors worked iteratively on the analysis of data, with periodic meetings with the fourth author. We developed a step-wise process (Table 3) congruent with the characteristics of grounded theory analysis (Charmaz 2014). Driven by constant comparison, the analytical process provided multiple opportunities for individual and group cross-checks of our analysis. We used NVivo qualitative analysis software (Version 11) for the initial individual open coding and for memo writing.

In Step 1 of our analysis (individual analysis), following Charmaz (2014), the first three authors completed line-by-line coding of interview transcripts using gerunds to describe actions and processes. Gerunds are verb-forms of nouns that keep coding focused on action and process, rather than merely description. We focused on identifying and describing codes rather than a priori coding, and we used constant comparison of coding categories, interpretive themes, and analytical process throughout. Individual coding was followed with descriptive and diagrammatic memoing to develop categories and themes for the design teams' processes.

Following the individual coding and memo process, the first three authors met as a group for Step 2 (group analysis): a consensus meeting to discuss analytical impressions from Step 1. These 1- to 2-h consensus discussions concluded with the research team developing a graphic process map to describe the issue-selection process for each design team (Step 3; team process mapping). Creating visual maps of processes or concepts assisted researchers in making sense of complex processes, crafting theory from data (Daley 2004; Glaser and Strauss 1967; Miles et al. 2014; Wheeldon and Faubert 2009). Following this, each researcher engaged in Step 4 (individual analysis and reflection), writing memos to capture details of the consensus meeting 
Table 3 Methodological pattern of step-wise data analysis used to generate grounded theory for forming design teams and selecting SSI

\begin{tabular}{|c|c|c|c|}
\hline \multicolumn{2}{|c|}{ Analytical steps } & \multirow{2}{*}{$\begin{array}{l}\text { Actions } \\
\begin{array}{r}\text { Open coding and } \\
\text { memo writing }\end{array}\end{array}$} & \multirow{2}{*}{$\begin{array}{l}\text { Analytical description } \\
\text { Line-by-line coding focused on actions and processes } \\
\text { Developed categories and themes } \\
\text { Constant comparative analysis }\end{array}$} \\
\hline Step 1 & $\begin{array}{r}\text { Individual } \\
\text { analysis }\end{array}$ & & \\
\hline Step 2 & Group analysis & $\begin{array}{l}\text { Open and axial } \\
\text { coding }\end{array}$ & $\begin{array}{l}\text { Refined categories and themes } \\
\text { Group consensus on design team process } \\
\text { Constant comparative analysis }\end{array}$ \\
\hline Step 3 & $\begin{array}{l}\text { Team process } \\
\text { map }\end{array}$ & Mapping & $\begin{array}{l}\text { Group development of visual map of design team process } \\
\text { Constant comparative analysis }\end{array}$ \\
\hline Step 4 & $\begin{array}{l}\text { Individual } \\
\text { analysis and } \\
\text { reflection }\end{array}$ & $\begin{array}{l}\text { Reflective memo } \\
\text { writing }\end{array}$ & $\begin{array}{l}\text { Captured reflection on analytical process immediately } \\
\text { following group analysis } \\
\text { Constant comparative analysis }\end{array}$ \\
\hline Step 5 & $\begin{array}{l}\text { Theory } \\
\text { refinement }\end{array}$ & $\begin{array}{l}\text { Mapping and } \\
\text { refinement }\end{array}$ & $\begin{array}{l}\text { Refined grounded theory based on constant comparative } \\
\text { analysis of design teams }\end{array}$ \\
\hline Step 6 & Trustworthiness & Mapping & $\begin{array}{l}\text { Return to data for final trustworthiness check by mapping } \\
\text { each team to the grounded theory and checking for } \\
\text { variation }\end{array}$ \\
\hline
\end{tabular}

and final reflective thoughts on the curriculum development process for each design team. Constant comparison of our coding categories, emergent themes, and analytical process occurred throughout the analysis. For our initial analysis, we purposefully chose three design teams that represented diverse teaching experience levels, demographics, and curriculum design processes. We individually analyzed the data from the three design teams following Steps 1-4. We then met as a group and used our analysis of the three groups to form a tentative, preliminary grounded theory model.

Analysis of the data from the remaining five design teams proceeded in the same fashion as before, meeting weekly to perform Steps 1-4 of the analysis pattern. At this point, however, we added an additional step to our process - Step 5 (theory refinement), during which we used constant comparison to revisit and revise our earlier coding, categories, and grounded theory model. Here, our focus was on interrogating how well the codes, categories, and grounded theory model captured the issue-selection process and tensions experienced during the PD. This theory refinement step represents the continuous revision and refinement of the grounded theory model. Next, we presented the revised grounded theory model to other researchers removed from the grounded theory development but familiar with the workshop in order to see if the model was easily interpretable and consistent with their observations of the workshop and design team processes. In this meeting, attention was given to examining if each design teams' curriculum design process could be mapped to this grounded theory model. These discussions prompted revisions on what then became the final grounded theory model. Finally, we performed Step 6 where we mapped each design team to our final grounded theory model. Step 6 (trustworthiness) was a systematic checking of how each design team fit with our final grounded theory, and it enabled us to confirm that our final grounded theory model functioned well to describe the collaborative design processes of our bounded case.

To summarize, we provide a visual schematic overview of our analysis process shown in Fig. 2. Briefly, the design teams within the bounded case of the PD workshop are shown at the top of the figure. We began by purposefully selecting three diverse design teams and analyzed each one's data using Steps 1-4 (see Table 3). The analysis from these three design teams 
resulted in the production of an initial, tentative grounded theory model. The remaining five design teams were analyzed using Steps $1-4$, followed by a revision and refinement step. This step, Step 5, was the constant comparison of processes and factors within and between each group in order to revise and refine our grounded theory model. Upon completion of Step 5 for all design teams, we presented our grounded theory model to other researchers familiar with the PD workshop for feedback. Finally, after all eight teams were analyzed and our final grounded theory model was generated, we performed an additional trustworthiness step, Step 6 , which involved mapping each design team back to the grounded theory.

\section{Data Interpretations}

Grounded theories informed by symbolic interactionism aim to illuminate collaborative and situated processes generated though shared symbolic meanings. Our grounded theory (Fig. 3) illustrates the process of SSI selection by collaborative teacher design teams nested in this SSI PD. In addition, it explicates the team genesis as integral and essential to the issue selection process. Categories and dimensions are conceptual elements of grounded theory generated from data (Charmaz 2014; Strauss and Corbin 1998). Categories represent the largest conceptual element of a grounded theory. In our model, categories are represented as square boxes and each category provides a response to our research questions. Categories are further elaborated by dimensions, shown as lists or objects within categories. Our grounded theory presents a fluid process of forming teams and selecting an issue. Within this process, tensions were produced which are represented as horizontal double arrows. As a result of encountering tensions, teachers made agential moves in order to continue toward their shared goal of issue selection. We define agential moves as capacities that teachers mobilized in response to encountered tensions. Agential moves are rooted in how we are defining agency, where agency is the real or perceived capacity to act in one's context, which impacts how teachers make their way through the worlds they inhabit (Richmond 2016). Next, we present an

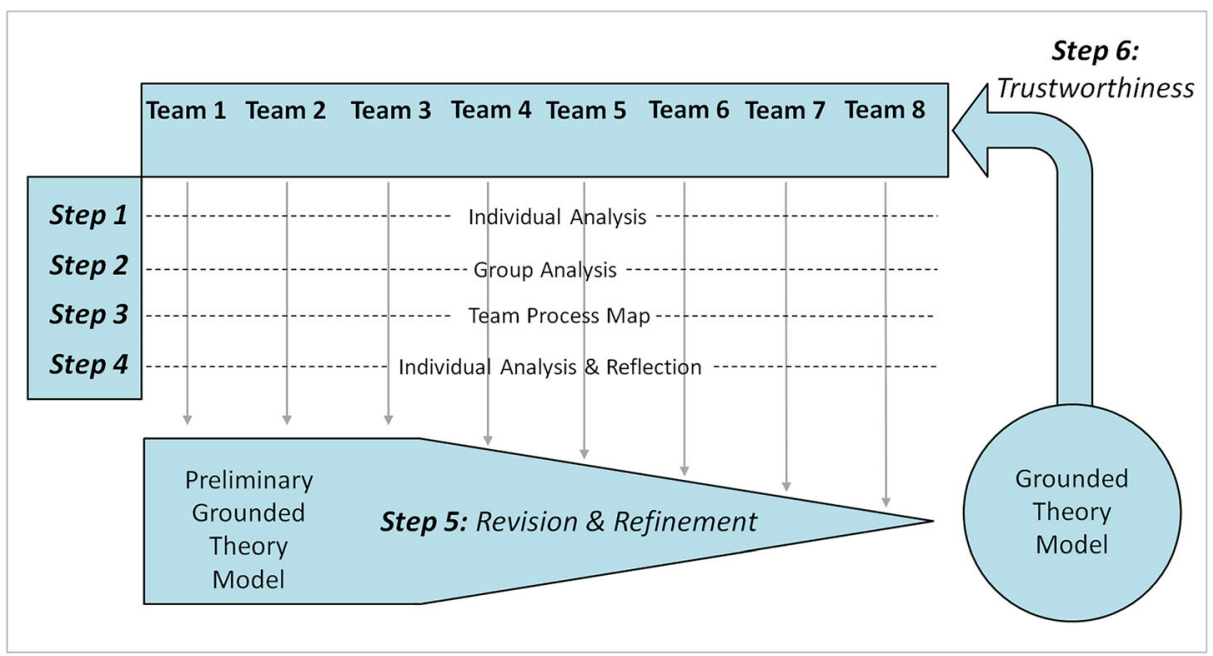

Fig. 2 Summative map of methodological pattern of step-wise data analysis process used to generate grounded theory for forming design teams and selecting SSI 


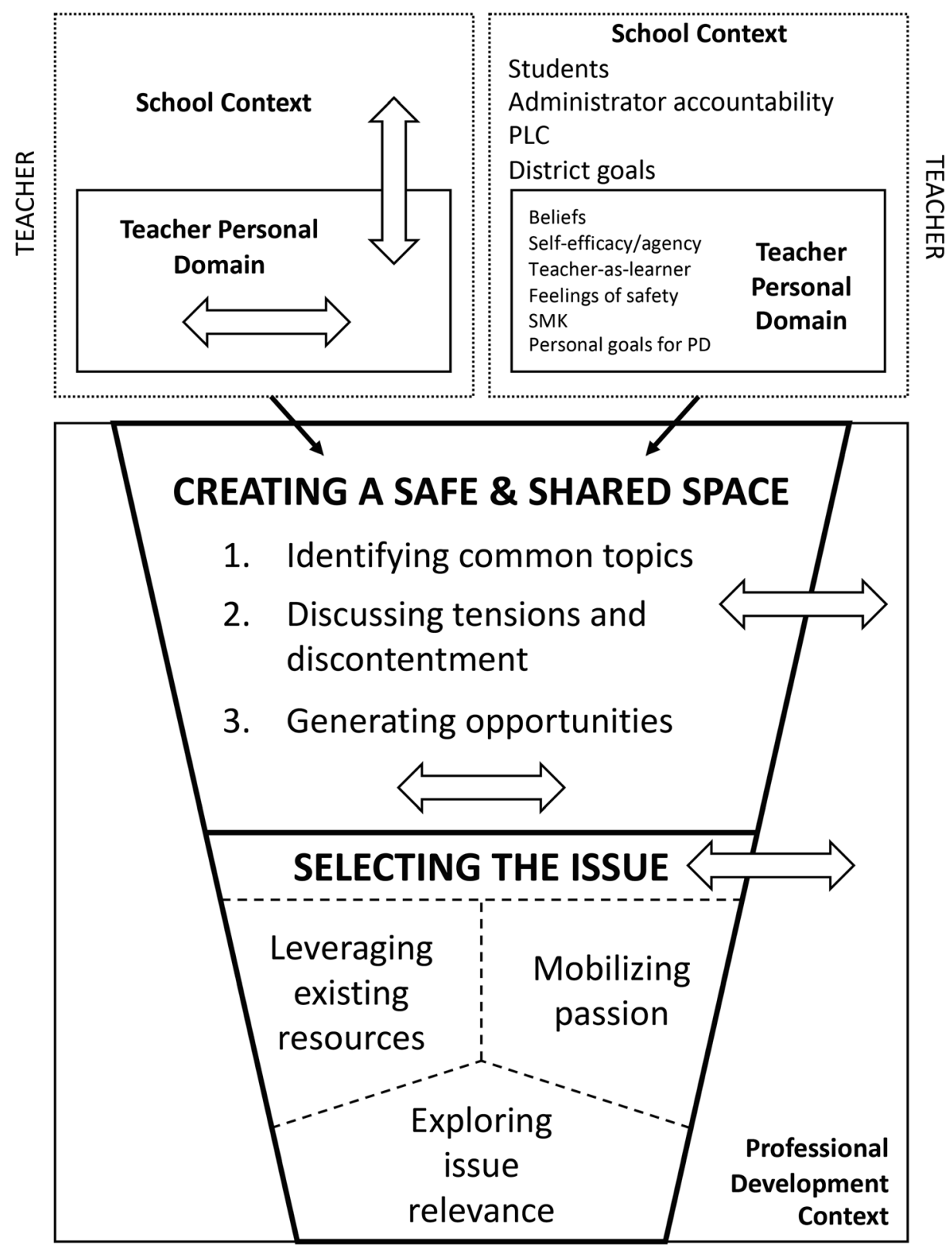

Fig. 3 Grounded theory model for design team formation and collaborative SSI selection. To facilitate reading, the dimensions for the Personal Domain and School Context are shown for only one teacher, and tensions are only shown the other teacher, despite the fact that these dimensions, tensions, and agential moves apply to all teachers. Prior tensions and/or those produced in process are represented by double-sided open arrows. Agential moves, i.e., navigation and/or negotiation, counter these tensions, are many, and therefore are not visually represented 
overview of this grounded theory, followed by a clarification of grounded theory, agential moves, and tensions through a narrative elaboration that highlights three design teams.

\subsection{Grounded Theory for Design Team Formation and Issue Selection}

At the top of Fig. 3, we show two teachers who join together to form a design team. Each teacher has their own Personal Domain situated within a specific School Context, all of which contains dimensions influential to their participation in the PD and the generation of shared meanings. The Personal Domain included beliefs about teaching and learning and beliefs about self-efficacy and agency, the stance toward "teacher as learner," feelings of safety with regard to experimenting with their teaching practice, depth of subject matter knowledge (SMK), and individual goals for participating in the PD. The salient dimensions of the School Context included students, influence of a professional learning community (PLC), school district goals, and administrator accountability with regard to the state end-of-course (EOC) examination and/or the adoption of the NGSS. Tensions existed within a teacher's Personal Domain and between their Personal Domains and School Contexts. Teachers made agential moves in their School Context and during the PD. (To facilitate reading Fig. 3, the dimensions for the Personal Domain and School Context are shown for only one of the two teachers and tensions are shown for the other teacher, despite the fact that these dimensions, tensions, and agential moves apply to all teachers in the PD.) Together, the two boxes at the top of Fig. 3 represent the complex Personal Domains and School Contexts that influenced the teachers' issue-selection process, which serve as a contextual backdrop to our grounded theory. These interpretations confirm previous findings that teachers' beliefs and school contexts influence their work in professional development settings (e.g., Clarke and Hollingsworth 2002; Friedrichsen and Dana 2005).

The large lower box in Fig. 3 represents our grounded theory for how teachers formed teams and selected an issue for their co-designed curriculum unit. The first category, Creating a Safe and Shared Space, consists of three sequential dimensions: (1) Identifying common topics that were taught, (2) discussing tensions and teaching discontentment, and (3) generating opportunities. During this category, teachers experienced tensions among their School Context, the PD workshop expectations, and with other teachers in the PD. As a result, teachers made agential moves to help create a safe and shared space with other teachers in their design teams and to move to the next category, Selecting an Issue. This category consisted of three iterative dimensions: leveraging existing resources, mobilizing passion, and exploring issue relevance. Design teams entered at different dimensions (e.g., exploring student relevance versus mobilizing passions) and the design teams spent differing amounts of time exploring each dimension. Again, teachers experienced tensions with other design team members and with the expectations of the PD. As teachers experienced these tensions, they made agential moves to resolve them.

\subsection{Grounded Theory Explication Using Three Design Teams}

The grounded theory, shown in Fig. 3, was derived from data associated with all eight design teams. However, we explicate the theory by presenting details from the processes of three teams to highlight theoretical features. This is intended to provide consistency and familiarity with those personal and contextual nuances that imparted rich detail to the development of our theory. Because this processual theory is robust enough to explain each design team's variation 
on success, we also highlight a few examples from other groups as evidence to this robustness and explanatory power beyond the highlighted teams. Briefly, those three teams are Jemma and Adam, George and Rebecca, and Marie and Julia (all pseudonyms). Details of these teams are provided in Table 2. First, we elaborate the personal and contextual domains of these three pairs before explicating our grounded theory.

\subsubsection{Personal Domain}

Adam and Jemma were veteran teachers who viewed their school contexts similarly-state exam focused, driven from the top-down by administrators. Both teachers were from the same region of the state and knew of each other from environmental science competitions but had not worked together before the PD. Jemma had a strong sense of self-efficacy and agency in her school context and was excited about the possibility of sharing the curriculum unit with other teachers through the project website. In contrast, Adam was unfamiliar with the NGSS and expressed concerns that he would not be able to make a non-traditional unit palatable to his community stakeholders (Field Notes). Adam struggled to see himself as capable of designing, let alone implementing, an SSI-based unit (Interview).

George and Rebecca were mid-career teachers who both identified as learners dissatisfied with aspects of their current teaching (Team Interview). Rebecca worked in a school that adopted Problem Based Learning (PBL) (Torp and Sage 1998) and co-taught a Biology and Literature course with an English teacher. George taught in a school with an International Baccalaureate (IB) program, and taught an IB Biology course. Neither felt pressured by high stakes testing, and both were creative experimenters in their classrooms, commonly trying new pedagogical strategies to make learning relevant for their students. They saw the opportunity to collaborate with other teachers as an opportunity to rejuvenate their intrinsic joy of teaching. Although they met for the first time at the PD, they quickly found common ground in their beliefs about teaching and their stance as teacher learners (Team Interview).

Marie and Julia were early career teachers who taught in the same school with classrooms next door to each other. Additionally, they were best friends and commonly spent time socializing outside of school. Marie had a degree in chemistry, while Julia had a biology background but was now teaching chemistry. At times, Julia lacked confidence in her chemistry SMK (Field Notes; Team Interview) and turned down some ideas "just because I was very intimidated by the science" (Team Interview). They both were bewildered yet honored their administrator supported their workshop attendance, and both maintained excitement for extending their close friendship into a new endeavor (Team Interview).

\subsubsection{School Context}

Teachers entered into the PD in a variety of affiliation combinations: as a solo teacher from a school district (e.g., Adam, Jemma, George, and Rebecca), as teachers from the same school district, or as a pair of teachers from the same high school science department (e.g., Marie and Julia). Regardless of their affiliation with other teachers, each worked within a specific high school context that offered both supports and barriers to their work in the PD, which bore upon the process of issue selection. For instance, George and Rebecca taught in schools that supported innovation (e.g., PBL). Marie and Julia taught in a high school in an urbanized school district already in the process of aligning curriculum with the NGSS, so the PD was consistent with their school's goals. Jemma and Adam taught in conservative and rural or urbanized school districts, 
respectively, with administrators who placed heavy emphasis on preparing students for the state biology exam. Their schools' high stakes test accountability represented a potential barrier for Adam and Jemma implementing a SSI-based unit. The presence and influence of PLCs in schools were both a potential support and a potential barrier to implementing a SSI unit, depending on whether teachers in a given PLC taught the same curriculum units and used common assessments. Marie and Julia made up the Chemistry PLC at their school, so this was a support structure for them. For others, who did not have PLC members at the PD but would be held accountable to their PLC's pacing schedule, this was a potential barrier. George was the solo Honors Biology instructor in his school, and Rebecca planned to implement the SSI-based unit in her combined Biology and Literature course wherein she was only accountable to her co-teacher rather than to multiple teachers in her Biology PLC.

Within the school context, teachers embodied a unique personal domain consisting of a complex set of knowledge and beliefs related to science teaching. They varied in the depth of their SMK and self-efficacy for teaching science; George, Rebecca, Jemma, and Adam were confident in their SMK, while Julia, and to some extent, Marie, lacked confidence in teaching some chemistry topics. Related to SMK and self-efficacy were feelings of safety associated with teaching a SSI-based unit. Marie and Julia were concerned about being novices in their careers and managing controversial social issues in their science classrooms. In discussing their issue-selection process, they were careful to avoid issues with "deep seeded feelings" that students would feel "morally convicted to choose a side" (Marie, Team Interview). Adam expressed confidence that he could meet the demands of his administrator, have his students do well on the state exam, and then afterwards "[teach] however I want to teach" (Team Interview). At the same time, he was also keen on maintaining his safety, stating he did not plan to share this strategy with his principal. The teachers varied in their stance as learners. George and Rebecca were eager to explore and learn more about the social aspects of potential issues and to try new pedagogical approaches. Marie and Julia felt safer sticking with chemistry content that they understood, often rejecting unfamiliar topics posed by PD facilitators. As a learner, Adam sometimes felt overwhelmed because of his unfamiliarity with the $N G S S$. The teachers varied in their pedagogical knowledge of and skill in designing curriculum. Although some were highly skilled and had led curriculum design work in their PLCs (e.g., Rebecca), others lacked curriculum planning experience. Categories and associated dimensions of the SSI selection process are explicated next, followed by elaboration of the process by way of tensions and agential moves.

\subsubsection{Creating a Safe and Shared Space}

The first category in the grounded theory, Creating a Safe and Shared Space, explains the process of how teachers formed curriculum design teams. The process of creating a safe and shared space, or forming curriculum design teams, is characterized by shared sequential movement through three dimensions: identifying common topics, discussing tensions and/or discontentment, and generating opportunity. To begin, the teachers shared and identified common topics they taught, and discussed how they grouped and sequenced topics in their courses. In the larger discipline-based groups (e.g., biology) in which individuals were not acquainted with each other, finding common topics that they taught acted as a form of currency that facilitated the making of teams. Although Marie and Julia arrived as a team, they struggled because they taught at different levels, honors, and introductory, and wanted "something that we could do in both classes" (Marie, Team Interview). 
After rapport was established and trust began to build, teams moved into the next dimension of this category-discussing tensions and/or discontentment. Here, teachers created a space where they shared their dissatisfactions and pressures related to teaching. For instance, Adam and Jemma were able to connect through their contextual tensions, "both of us are in [state exam] driven classes, we know it's lockstep... so, we looked at each other like, every single thing we do in here has to hit a major instructional goal" (Jemma, Team Interview). George and Rebecca were both dissatisfied with the ways they taught photosynthesis and respiration, and this was a personal tension for them both. George described his most recent attempt at these topics as a "dumpster fire" and expressed his frustration with his lack of planning (Team Interview). Marie and Julia were frustrated as they struggled with the myriad tensions in and out of the PD. Julia described being scared and intimidated, because her "chemistry is not that strong" and she worried whether her "intro chem kids would be fine with [the unit]" (Team Interview). Marie expressed being dissatisfied with the idea that their unit would not be something that both she and Julia could use, and so they discussed many topics at length.

The final dimension of this category was generating opportunities. George and Rebecca saw the PD as an opportunity to design a more engaging unit on the topics of photosynthesis and respiration (Team Interview). Marie and Julia searched for a topic they could both teach and discussing ionic compounds generated the "we could both do this" opportunity they sought (Team Interview). Jemma and Adam diverged from these shared visions and instead generated individual opportunities. Jemma saw the PD as an opportunity to design a curriculum unit that she could use in her application for National Board Certification. For Adam, the SSI-based unit provided the opportunity to both meet the administrative state exam demands as well as provide the means for students to engage with the social and ecological dimensions of his content, and hopefully arriving at an impetus to be stewards for the environment (Team Interview). These established opportunities were forces that aggregated the teachers into design teams of their choosing, moving them closer to selecting their issues.

\subsubsection{Selecting the Issue}

The final category of the grounded theory, Selecting the Issue, provides an explanation of the process of focal issue selection. Selecting the Issue was defined by iterative discussion in three dimensions: leveraging existing resources, mobilizing passions, and exploring issue relevance. These categorical dimensions were not sequential, unlike those in the first category, but cyclical and inter-related. Teachers entered this category by focusing on one of the three dimensions, and mobilizing passion was a common entry point for this cyclic category. The mobilizing passion dimension was where teachers operationalized their passions, transforming them into a resource for unit development. The teachers often commented that this was a key step in the process. George and Rebecca shared a passion for equitable food access and social justice, which catapulted them further in the issue selection process (Team Interview). Adam explained that he had "been investigating invasive species for about the last 10 years" on his own time (Team Interview). Operationalizing this passion, his issue selection focused on developing a unit around invasive species. Jemma was also passionate about ecology and native species, so for this team, their shared passion provided the issue they would use for curriculum design. Yet, this shared passion for the issue was not common across teams, and it was often one teacher who voiced a strong passion, and then recruited and rallied their design teammates to this impassioned issue. For instance, Marie was a vegetarian who was passionate about not eating meat and this was important to her when selecting a socio-scientific issue, "I 
don't want to do something I don't care about or I'm not interested in" (Team Interview). Julia recalled being recruited into Marie's passion and then together "[running] away with the idea" of food additives in meat (Team Interview).

The leveraging existing resources dimension was characterized by teachers drawing upon and exploiting past teaching experiences and/or teaching resources. Marie and Julia had piloted a lesson the previous year that focused on food coloring, so the issue of food preservatives felt like a natural extension to them. Both Adam and Jemma had large outdoor gardens and learning areas at their schools that they leveraged. Each of them had given short presentations on invasive species as part of their existing ecology units. Furthermore, Jemma had used invasive species as the centerpiece of her ecology unit in the past year, so she drew upon those resources in her issue-based unit. The final dimension in this category is exploring issue relevance. For some, this exploration was explicit; for others, it was defined by discussions about stakeholders relevant to the teachers; and in some teams, this dimension received cursory attention. For example, Marie and Julia were devoted to thinking about issue relevance from their students' perspective, but as early career teachers, they wanted to select an issue that would not cause students to be "super emotional about it" (Marie, Team Interview) but "just maybe enough" (Julia, Team Interview). Similarly, George and Rebecca felt that their students would like the controversy associated with their fat tax issue and it would spark enthusiasm and interest in their students. Particularly, their students would "grab onto that idea of injustice" (Rebecca, Team Interview). Jemma claimed that to remain relevant to students "we have to deliver what they're learning through technology," yet contended she could make anything relevant as long as she was interested in it (Team Interview).

\subsubsection{Tensions and Agential Moves}

The grounded theory describes the teachers' process of selecting a socio-scientific issue and co-designing a curriculum unit around it. Embedded within this process are two reciprocal and reinforcing concepts: tensions and agential moves. The tensions in teachers' Personal Domains and School Contexts were carried forward into their design team process. Furthermore, within each category of the grounded theory, additional tensions were produced and encountered. Tensions are forces which pull between two seemingly oppositional forces that cut through an individual, producing "internal turmoil" (Berry 2008, p. 32). These tensions can be productive, generating apparently immovable glaciers that must be navigated around or contingent matters that can be negotiated (Evans 2002). Agency is the real or perceived capacity to act in one's context, which plays a critical role in how teachers make their way through the worlds they inhabit (Richmond 2016). We define agential moves, i.e., navigation and negotiation, as those capacities that teachers mobilized in response to the tensions they encountered. Agential moves are how teachers took ownership of tensions and moved toward selecting a SSI. The progression toward selecting a SSI was complex and generated many tensions. These tensions necessitated agential moves that were facilitated through situated actions and interactions of design team members, PD facilitators, or other materials. Next, we discuss the tensions and agential moves associated with forming a design team and selecting a SSI.

Involvement with the PD produced a tension between the teachers' goals and their school context. This primarily occurred when many teachers established personal goals for the PD (e.g., re-design a cellular respiration unit), and for some, this goal setting was unproblematic. Yet for others, it produced a tension with their PLC, which followed a pacing schedule, used the same teaching materials, and/or common assessments. To negotiate this, some teachers intended to 
return to their PLC and share the SSI-TL framework (Sadler et al. 2017) alongside their new SSIbased curriculum unit. For example, Jess, a chemistry teacher who works in a PLC that teaches at the same pace from the same PowerPoint notes, hoped sharing her SSI unit and the framework would help them to be "open for change ... and [want] to try new things" (Interview). Conversely, other teachers navigated this tension by planning to implement their SSI-based curriculum unit without informing their PLC. For instance, Judith, a biology teacher in a large PLC that followed similar pacing and used common assessments, planned to do just that. Both Marie and Julia felt like the PD workshop was an opportunity to work together to produce a cohesive unit they both could teach. However, this egalitarian goal produced a tension that necessitated an imbalanced approach. Julia's discomfort with her SMK and need to meet the needs of her introductory chemistry course were tensions the team resolved through agential moves. Because her discomforts were not dissipating, this move was a navigation by way of negotiating content to meet their shared personal goals and defined opportunities for the PD.

In the Safe and Shared Space category, several tensions were substantial. A complex tension developed between the PD facilitators and the teachers when the latter were asked to establish design teams of 2-3 members. Within the large group of biology teachers, no prior relationships had been established, so the teachers needed to navigate and negotiate their shared tensions, as well as those tensions produced when they made moves to form small design teams. George and Rebecca described this process as messy; Rebecca went on: "it was just a lot of talking in circles and talking about all the directions we could go" (Team Interview). As the design teams were formed and became more acquainted with one another, tensions between the team members occurred. For some, it required negotiating which opportunity to pursue, often requiring teachers to revisit their own goals and again make agential moves. George was fixed on reworking and incorporating a cell membrane unit and initially was disappointed when he realized that he was not going to use this time to "make [his unit] better" (Team Interview). For others, it was unresolved tensions produced from a default association process that established their design team when other teachers arrived in pairs. For instance, because Marie and Julia did not consider renegotiating their partnership, the two remaining chemistry teachers, Jess and Tonya, were forced to work together, requiring substantial agential moves to work within their default team affiliation. Jess and Tonya failed to create a safe and shared space producing new tensions for them. They navigated around these emergent tensions and the expectation to work as a team, and instead individually generated opportunities loosely tied together with their selected theme of water.

The iterative processing in the Selecting the Issue category produced cycles of tensions and various agential moves. For some teachers and some teams, the PD facilitators' expectations of a full unit centered on a focal issue and aligned with the NGSS, as well as their own contextual accountability measures, were overwhelming. Adam felt lost, "when I left [the March workshop], I thought my head was gonna explode, because it was pretty open ended" (Team Interview). However, he negotiated this tension with assistance from Jemma who helped him see how all the parts fit together. She navigated their discussions away from details and toward big themes that could loop back to native and invasive species (Team Interview; Field Notes). Jemma's agential moves supported Adam making his own agential moves — navigating around district state exam mandates by creative sequencing - which resolved his individual tensions. This generated a collective opportunity for the team to tackle Selecting the Issue. George and Rebecca moved through the cyclic work of Selecting the Issue with ease, and like Marie and Julia, they found that sharing documents online facilitated their work. For these teams, the online support was integral to their group process and facilitated individual and group agential 
moves, enabling them to arrive at selecting a socio-scientific issue. The online sharing provided a concrete means to be accountable and supportive, as well as a tool for setting goals, preempting paralysis by tensions.

\section{Discussion}

To date, the collaboration literature has focused on the reasons, the requirements, and the effects of collaboration, but not on the phenomenon of collaboration itself (Vangrieken et al. 2015). This study answers Vangrieken et al.'s call for research on the actual process of collaboration. In addition, SSI research has focused on teachers' use of prepared SSI-based curricular materials and/or teachers under close guidance or collaboration with researchers (e.g., Klosterman and Sadler 2010; Marks and Eilks 2009; Peel and Friedrichsen 2018; Presley et al. 2013). In contrast, we highlighted what teachers did and what they did together when challenged to develop SSI teaching materials for their own use, beginning to fill a gap in scholarship, as well as highlight their processes from the teachers' points of view. This work is important because it advances scholarship that could build teacher capacity to independently select socio-scientific issues and develop SSI-based curricula. Our focus on new and emergent tensions associated with design team dynamics adds to the literature in ways that move beyond attention to products of the collaborative process.

The teacher collaboration literature identifies the need for teachers to feel safe in order for teacher learning to occur (Kelchtermans 2006). This study adds to the literature by identifying the sequential process that teachers went through to create a shared and safe space for collaboration. In addition, prior SSI research has focused on teachers' orientations toward SSI teaching (Barrett and Nieswandt 2010). This perspective, however, differed from what we found from the teachers' points of view in Creating a Safe and Shared Space. We found that identifying common topics was a more important form of currency for teachers, rather than their orientations toward using SSI. Further, this exchange was an important starting point for them in the process. These common topics provided starting points and shared meanings that fostered necessary agential moves to counter the tensions in the collaborative issue selection process. These findings shift the focus toward team dynamics as integral to the issue selection process, as well as collaborative curriculum design, which adds to scholarship that focuses on PD provided supports (see Huizinga et al. 2014; Binkhorst et al. 2015; Olin and Ingerman 2016).

The Selecting the Issue category was characterized by several interrelated dimensions: relevance, leveraging existing resources, and mobilizing passions. Indeed, a central element to SSI is relevancy (Marks and Eilks 2009; Hofstein et al. 2011; Kolstø 2001; Levinson 2006; Marks and Eilks 2010), yet our findings place relevance as an important and interdependent construct of the issue selection process rather than a starting point. Those few teams who struggled with connecting their issue locally were often "stuck" in this category and struggled to progress toward issue selection, focusing instead on broad, global topics, (e.g., water quality or food additives). In those teams where student relevance was a primary driver, their issue explicitly leveraged recent community events (e.g., local flooding), popular movies (e.g., The Martian), or student resources and experiences (e.g., drug testing in high school athletes). These foci are related to two of the four types of relevance described by Van Aalsvoort (2004), personal relevance, and personal/social relevance; the teachers in our study did not consider professional or social relevance of an SSI. These choices, which connected students' personal 
lives and scaffolded making personal community connections, followed recommendations for making SSI and science relevant (Sadler 2004).

Being able to leverage existing resources influenced the design teams' selection of their socio-scientific issue, which adds to the literature on supporting SSI-based teaching and has implications for PD. In discussing a potential SSI, the design teams considered their available resources. These existing resources were broadly conceptualized, encompassing SMK related to the science in the SSI, prior teaching experiences, instructional materials, and physical settings such as outdoor classrooms and gardens. This practical consideration of resources mirrors what Doyle and Ponder (1977) proposed regarding teachers' practicality ethic. That is, teachers continuously receive messages about improvement and they evaluate them based on practicality, which highlights how the decision-making process for issue selection was, in part, driven by practical considerations of available resources. Next, the teachers needed to transform those resources, which reminds us of François Jacob's (1977) essay, Evolution and Tinkering, in which he uses the metaphor of natural selection as a tinkerer that modifies existing material. He stated, "novelties come from previously unseen association of old material. To create is to recombine" (p. 1163). For example, the design team who chose local flooding as a focal issue for their unit discussed how they could use some instructional materials from two existing curriculum units, soil, and water, which they had previously taught as unrelated topics. Practically considering how to leverage and tinker with existing resources helped the design teams envision how they would shift their practice to using a SSI-based approach. Friedrichsen and Barnett (2018) reported similar findings in the context of a PLC re-designing their curriculum to align with the NGSS; the teachers used an existing resource, a writing rubric, to help them reenvision their curriculum and teaching practice.

Mobilizing passions was an unexpected dimension of Selecting an Issue and is a contribution to the literature. Charmaz (2014) positioned moments where understandings change as those that have the power to make visible and interpretable the ongoing nature of knowledge production and meaning-making shared through discourse. As PD facilitators, we had not fully recognized how our own passions influenced issue selection in our initial efforts to design SSI-based units. One of the facilitators was an avid birder and shared an SSI unit using the issue of a local proposal to construct an ethanol plant that would affect bird habitat. Another facilitator, a former nutritionist, shared an SSI unit using the issue of a "Fat Tax" on obesogenic foods. A third facilitator, passionate about evolution education, shared a natural selection unit using the issue of antibiotic resistance. (These units are available at: http://ri2.missouri.edu/). The passions we displayed became symbolic for the teachers, and this emerged as a theme in the team and individual interviews where teachers talked about the passion they saw in the PD facilitators. Mobilizing passion was a vibrant force for teachers that supported their capacities to generate opportunities to select SSI, as well as connect, and in some cases, reconnect their passions to their teaching. Vallerand (2008) defined passion as "a strong inclination toward an activity that people like, find important, and in which they invest time and energy" (p. 1). Mobilizing teacher passion is a worthwhile pursuit as passion for teaching can lead to increased job satisfaction, motivation, and self-efficacy (Day 2004), as well as decreased teacher burnout (Carbonneau et al. 2008). Within design teams, it was often one teacher who was passionate about an issue which led to the team selecting that issue. This required the passionate teacher to act in ways that facilitated buy-in through the collaborative 
process and shared meaning. These findings suggest that scaffolding team dynamics could be helpful for supporting teachers in collaborative SSI-based curriculum design.

In this study, passion for an issue was an entry point for teachers into SSI-based teaching. Lee and Witz (2009), studying four science teachers who adopted SSI teaching on their own without broader curriculum reform efforts, reported that the teachers did so because it aligned with their deeper values and ideals. Our study occurred within a curriculum reform effort, a SSI-based PD, and sheds light on how teachers might be introduced to SSI-based teaching as it revealed that passion for an issue can be a powerful gateway into this teaching approach. As a field, we need to move beyond small numbers of teachers who take up SSI-based teaching on their own or implement SSI units primarily designed by researchers. We can draw upon teachers' passions for particular issues to build capacity for SSI-based teaching.

Tensions, associated agential moves, and their reciprocal relationship represent the dynamic forces that were woven throughout the issue selection process and associated grounded theory. Symbolic interactionism emphasizes processes and those meanings, interactions, and actions that make the process work (Benzies and Allen 2001; Charmaz 2014). This highlighted how the issue selection process was messy, complex, and dynamic. Many of our participant teachers expressed tensions with how SSI initiates controversial conversations in their classrooms, similar to other teachers who worked with SSI (Bryce and Gray 2004; Day and Bryce 2011). Teams required time and space to grapple with these tensions as well as others, including those produced while generating shared meanings while selecting an issue. These shared meanings, like what constitutes a "good issue," empowered the agential moves necessary to navigate or negotiate tensions to produce units that would work in the teachers' own contexts. These findings provide additional insights as to why teachers who work alone are likely to be unprepared to teach complex issues (Fensham 2012). Despite this value of collaborative work, teacher collaboration can lead to conflict (Kelchtermans 2006; Vangrieken et al. 2015). By paying close attention to tensions, this study contributes to the literature in describing how teachers negotiated and navigated these tensions, thus avoiding conflict. The importance of collaboration and shared meaning as primers for action further emphasizes the necessity of providing social supports for teachers during implementation.

\section{Limitations}

This study was a grounded theory study of bounded cased data. Accordingly, the substantive theory we developed only applies to our case. More research is needed to further substantiate and/or revise our theory based on additional teachers engaged in SSI curriculum design. In addition, this study was carried out with a group of science teacher in the USA and we acknowledge how PD programs, curriculum design and control, and teacher agency can vary widely based on local and national contexts and cultures. This variation in practices may limit the application of some of our findings and highlights the need for additional research with more teachers engaging in SSI curriculum design or teaching in diverse contexts.

\section{Conclusion and Implications}

This study problematized two aspects of SSI-based curriculum design teaching: how teachers form design teams and how they select socio-scientific issues. In our grounded theory, we 
interrogated and explained how these processes happened and the ways in which they were also under constant revision. Teachers brought with them ideals, tensions, and beliefs, and they needed to work with these personal factors in order to produce Safe and Shared Spaces with other teachers. This process was characterized by navigating and negotiating the tensions produced while identifying common topics, sharing discontentment, and generating opportunities. Teams moved to Selecting the Issue, where they began a circuitous process of engaging with the interrelated dimensions of mobilizing passions, exploring issue relevance, and leveraging existing resources. The capacity to act in response to both existing and emergent tensions was enabled through the collaborative process, which fostered the selection of a practical socio-scientific issue for the teachers' classrooms. This grounded theory study of how a group of teachers in a PD formed collaborative design teams and selected an issue for their SSI unit has implications for professional development and research.

PD providers should facilitate developing a shared and safe space for each design team. We recommend that time be given at the beginning of a PD to facilitate a discussion of commonalities among teachers, such as courses taught, student demographics, and administrator expectations, since these discussions helped teachers to form initial teams. Next, we recommend that PD providers facilitate discussions of teacher discontentment related to their practice and tensions they are experiencing. By acknowledging that tensions may exist between PD expectations, school contexts, and within design teams, a space is opened for teachers to discuss how they will negotiate and navigate these tensions, which may lead to greater attainment of the PD goals. By purposefully leveraging teacher discontentment as a gateway to opportunity, teachers can begin to envision how the PD might help them address aspects of their practice for which they are dissatisfied.

With regard to facilitating socio-scientific issue selection among teachers new to this teaching approach, teachers first need to understand the general characteristics of a SSI, specifically that SSIs are complex, sometimes controversial, social issues that revolve around scientific phenomena (Sadler 2011). To help teachers select from a multitude of relevant SSIs, we recommend that PD providers explore individual teacher's passions for an issue. We found this to be a powerful catalyst to ignite SSI-based teaching. We also recommend that PD providers assist teachers in exploring their existing resources, whether it is a physical setting, content knowledge, PCK, or existing curricular materials. By helping teachers see ways they can draw on their existing resources, a shift to SSI-based teaching may seem more attainable to teachers.

This study explored how collaborative curriculum design teams were formed and how design teams selected an issue for their initial SSI-based curriculum units. Our grounded theory is specific to this initial phase of curriculum development. There is a need for longitudinal studies of teachers as they implement SSI-based teaching. Inquiries that span teacher implementation would likely illuminate several questions critical for advancing the SSI agenda including the following: What unanticipated problematic aspects associated with the selected SSI emerge during classroom implementation? How do teachers perceive their students' responses to the selected issue? As teachers implement their initial SSI units, how do they identify the characteristics of a good SSI, and how does their issue selection criteria change and become refined over time?

Funding Information This material is based upon work supported by the National Science Foundation under Award Number IIA-1355406. Any opinions, findings, and conclusions or recommendations expressed in this material are those of the authors and do not necessarily reflect the views of the National Science Foundation. 


\section{Compliance with ethical standards}

Conflict of Interest The authors have no conflicts of interest to declare.

Open Access This article is distributed under the terms of the Creative Commons Attribution 4.0 International License (http://creativecommons.org/licenses/by/4.0/), which permits unrestricted use, distribution, and reproduction in any medium, provided you give appropriate credit to the original author(s) and the source, provide a link to the Creative Commons license, and indicate if changes were made.

\section{References}

Barrett, S. E., \& Nieswandt, M. (2010). Teaching about ethics through socioscientific issues in physics and chemistry: Teacher candidates' beliefs. Journal of Research in Science Teaching, 47, 380-401.

Benzies, K. M., \& Allen, M. N. (2001). Symbolic interactionism as a theoretical perspective for multiple method research. Journal of Advanced Nursing, 33(4), 541-547.

Berry, A. (2008). Tensions in teaching about teaching. New York: Springer.

Binkhorst, F., Handelzalts, A., Poortman, C. L., \& van Joolingen, W. R. (2015). Understanding teacher design teams: A mixed methods approach to developing a descriptive framework. Teaching and Teacher Education, $51,213-224$.

Bossér, U., Lundin, M., Lindahl, M., \& Linder, C. (2015). Challenges faced by teachers implementing socioscientific issues as core elements in their classroom practices. European Journal of Science and Mathematics Education, 3(2), 159-176.

Bryce, T., \& Gray, D. (2004). Tough acts to follow: The challenges to science teachers presented by biotechnological progress. International Journal of Science Education, 26(6), 717-733.

Carbonneau, N., Vallerand, R. J., Fernet, C., \& Guay, F. (2008). The role of passion for teaching in intrapersonal and interpersonal outcomes. Journal of Education Psychology, 100(4), 977-987.

Charmaz, K. (2014). Constructing grounded theory (2nd ed.). Thousand Oaks: SAGE Publications.

Clarke, D., \& Hollingsworth, H. (2002). Elaborating a model of teacher professional growth. Teaching and Teacher Education, 18(8), 947-967.

Coenders, F., Terlouw, C., Dijkstra, S., \& Pieters, J. (2010). The effects of the design and development of a chemistry curriculum reform on teachers' professional growth: A case study. Journal of Science Teacher Education, 21(5), 535-557.

Creswell, J. W. (2014). Research design: qualitative, quantitative, and mixed methods approaches: Thousand oaks: SAGE publications.

Daley, B. J. (2004). Using concept maps in qualitative research. Paper presented at the first international conference on concept mapping, Pamplona.

Davis, E. A., Janssen, F. J. J. M., \& Van Driel, J. (2015). Teachers and science curriculum materials: where we are and where we need to go. Studies in Science Education, 52(2), 127-160.

Day, C. (2004). A passion for teaching. London: RoutlegeFalmer.

Day, S. P., \& Bryce, T. G. K. (2011). Does the discussion of socio-scientific issues require a paradigm shift in science teachers' thinking. International Journal of Science Education, 33(12), 1675-1702.

de Putter-Smits, L. G. A., Taconis, R., Jochems, W., \& Van Driel, J. (2012). An analysis of teaching competence in science teachers involved in the design of context-based curriculum materials. International Journal of Science Education, 34(5), 701-721.

Denzin, N. K. (2004). Symbolic interactionism. In U. Flick, E. von Kardorff, \& I. Steinke (Eds.), A companion to qualitative research (pp. 81-87). Thousand Oaks: SAGE Publications.

Department of Elementary and Secondary Education (DESE). (n.d.). Missouri Comprehensive Data System. [School district data]. Retrieved from https://mcds.dese.mo.gov/quickfacts/Pages/District-and-SchoolInformation.aspx. Accessed 4 Jan 2017.

Doyle, W., \& Ponder, G. A. (1977). The practicality ethic in teacher decision-making. Interchange, 8(3), 1-12.

Drits-Esser, D. (2015). The impact of collaborative curriculum design on teacher professional learning. Electronic Journal of Science Education, 19(8), 1-27.

Eastwood, J. L., \& Sadler, T. D. (2013). Teachers' implementation of a game-based biotechnology curriculum. Computers and Education, 66, 11-24. 
Eastwood, J. L., Sadler, T. D., Zeidler, D. L., Lewis, A., Amiri, L., \& Applebaum, S. (2012). Contextualizing nature of science instruction in socioscientific issues. International Journal of Science Education, 34(15), 2289-2315.

Eilks, I. (2002). Teaching 'biodiesel': A sociocritical and problem-oriented approach to chemistry teaching and students' first views on it. Chemistry Education Research and Practice, 3(1), 77-85.

Ekborg, M., Ottander, C., Silfver, E., \& Simon, S. (2013). Teachers' experience of working with socio-scientific issues: A large scale and in depth study. Research in Science Education, 43(2), 599-617.

Evans, K. (2002). Negotiating the self: Identity, sexuality, and emotion in learning to teach. New York: Routledge-Falmer.

Fleming, R. (1986). Adolescent reasoning in socio-scientific issues, part I: Social cognition. Journal of Research in Science Teaching, 23, 677-687.

Fensham, P. (2012). Preparing citizens for a complex world: The grand challenge of teaching socio-scientific issues in science education. In A. Zeyer \& R. Kyburz-Graber (Eds.), Science/environment/health: Towards a renewed pedagogy for science education (pp. 7-29). Dordrecht: Springer.

Friedrichsen, P., \& Barnett, E. (2018). Negotiating the meaning of next generation science standards in a secondary biology teacher professional learning community. Journal of Research in Science Teaching, 55(7), 999-1025.

Friedrichsen, P., \& Dana, T. M. (2005). Substantive-level theory of highly regarded secondary biology teachers' science teaching orientations. Journal of Research in Science Teaching, 42(2), 218-244.

Friedrichsen, P., Sadler, T. D., Graham, K., \& Brown, P. (2016). Design of a socioscientific curriculum unit: Antibiotic resistance, natural selection, and modeling. International Journal of Designs for Learning, 7(1), 1-18.

Glaser, B. G., \& Strauss, A. L. (1967). The discovery of grounded theory. Chicago: Aldine.

Handelzalts, A. (2009). Collaborative curriculum development in teacher design teams. University of Twente.

Herman, B. C. (2015). The influence of global warming science views and sociocultural factors on willingness to mitigate global warming. Science Education, 99(1), 1-38.

Hofstein, A., Eilks, I., \& Bybee, R. (2011). Societal issues and their importance for contemporary science education: A pedagogical justification and the state-of-the-art in Israel, Germany, and the USA. International Journal of Science and Mathematics Education, 9(6), 1459-1483.

Huizinga, T., Handelzalts, A., Nieveen, N., \& Voogt, J. M. (2014). Teacher involvement in curriculum design: Need for support to enhance teachers' design expertise. Journal of Curriculum Studies, 46(1), 33-57.

Huizinga, T., Handelzalts, A., Nieveen, N., \& Voogt, J. M. (2015). Fostering teachers' design expertise in teacher design teams: Conducive design and support activities. Curriculum Journal, 26(1), 137-163.

Jacob, F. (1977). Evolution and tinkering. Science, 196, 1161-1166.

Janasoff, S. (2004). Science and citizenship: A new synergy. Science and Public Policy, 31(2), 90-94.

Janasoff, S. (2010). A new climate for society. Theory, Culture \& Society, 27(2-3), 233-253.

Jeon, Y. (2004). The application of grounded theory and symbolic interactionism. Scandinavian Journal of Caring Sciences, 18, 249-256.

Khishfe, R., \& Lederman, N. (2006). Teaching nature of science within a controversial topic: Integrated versus nonintegrated. Journal of Research in Science Teaching, 43(4), 395-418.

Kelchtermans, G. (2006). Teacher collaboration and collegiality as workplace conditions. A review. Zeitschrift fur padagogik, 52(2), 220.

Kolstø, S. D. (2001). Scientific literacy for citizenship: Tools for dealing with the science dimension of controversial socioscientific issues. Science Education, 85(3), 291-310.

Klosterman, M. L., \& Sadler, T. D. (2010). Multi-level assessment of scientific content knowledge gains associated with socioscientific issues-based instruction. International Journal of Science Education, 32(8), 1017-1043.

Kurtz, C. F., \& Snowden, D. J. (2003). The new dynamics of strategy: Sense-making in a complex and complicated world. IBM Systems Journal, 42(3), 462-483.

Lead States, N. G. S. S. (2013). Next generation science standards: For states, by states. Washington: National Academies Press.

Lee, H., Abd-El-Khalick, F., \& Choi, K. (2006). Korean science teachers' perceptions of the introduction of socioscientific issues into the science curriculum. Canadian Journal of Science, Mathematics and Technology Education, 6(2), 97-117.

Lee, H., \& Witz, K. G. (2009). Science teachers' inspiration for teaching socio-scientific issues: Disconnection with reform efforts. International Journal of Science Education, 31(7), 931-960.

Levinson, R. (2006). Towards a theoretical framework for teaching controversial socio-scientific issues. International Journal of Science Education, 28(10), 1201-1224.

Lewis, J., \& Leach, J. (2006). Discussion of socio-scientific issues: The role of science knowledge. International Journal of Science Education, 28(11), 1267-1287. 
Marks, R., \& Eilks, I. (2009). Promoting scientific literacy using a sociocritical and problem-oriented approach to chemistry teaching: Concept, examples, experiences. International Journal of Environmental \& Science Education, 4(3), 231-245.

Marks, R., \& Eilks, I. (2010). Research-based development of a lesson plan on shower gels and musk fragrances following a socio-critical and problem-oriented approach to chemistry teaching. Chemistry Education Research and Practice, 11, 129-141.

McFadden, J. R. (2015). Teachers as designers: The iterative process of curriculum design focused on STEM integration. (unpublished doctoral dissertation). University of Minnesota. United States.

McLaughlin, T. (2003). Teaching controversial issues in citizenship education. In A. Lockyer, B. Crick, \& J. Annette (Eds.), Education for democratic citizenship (pp. 149-160). Aldersot: Ashgate.

Merriam, S. B. (1998). Qualitative research and case study applications in education. San Francisco, CA: Jossey-Bass.

Miles, M. B., Saldaña, J., \& Huberman, A. M. (2014). Qualitative data analysis: A methods sourcebook (3rd ed.). Thousand Oaks: SAGE Publications.

National Academies of Sciences, Engineering, and Medicine. (2015). Science teachers' learning: Enhancing opportunities, creating supportive contexts. Washington, DC: The National Academies Press.

National Research Council (NRC). (2012). A framework for K-12 science education. [electronic resource]: Practices, crosscutting concepts, and core ideas: Washington, D.C.: National Academies Press.

NVivo (Version 11) [Qualitative data analysis software]. Burlington, MA: QSR International Inc.

Olin, A., \& Ingerman, Å. (2016). Features of an emerging practice and professional development in a science teacher team collaboration with a researcher team.

Pedretti, E. G., Bencze, L., Hewitt, J., Romkey, L., \& Jivraj, A. (2007). Promoting issues based STSE perspectives in science teacher education: Problems of identity and ideology. Science \& Education, 17, 941-960.

Peel, A., \& Friedrichsen, P. (2018). Algorithms, abstractions, and iterations: Teaching computational thinking using protein synthesis translation. American Biology Teacher, 80(1), 21-28.

Presley, M. L., Sickel, A. J., Muslu, N., Merle-Johnson, D., Witzig, S. B., Izci, K., \& Sadler, T. D. (2013). A framework for socio-scientific issues based education. Science Educator, 22(1), 26-32.

Ratcliffe, M., \& Millar, R. (2009). Teaching for understanding of science in context: Evidence from the pilot trials of the twenty first century science courses. Journal of Research in Science Teaching, 46(8), 945-959.

Richmond, G. (2016). Making sense of the interplay of identity, agency, and context in the development of beginning science teachers in high-poverty schools. In L. Avraamidou (Ed.), Studying science teacher identity. Boston: Sense Publishers.

Romine, W. L., Sadler, T. D., \& Kinslow, A. T. (2016). Assessment of scientific literacy: Development and validation of the quantitative assessment of socio-scientific reasoning (QUASSR). Journal of Research in Science Teaching, 54(2), 274-295.

Rotermund, S., DeRoche, J., \& Ottem, R. (2017). Teacher professional development by selected Teacher and school characteristics: 2011-12 (NCES 2017-200). Retrieved from https://nces.ed.gov/pubsearch/pubsinfo. asp?pubid=2017200

Sadler, T. D. (2004). Informal reasoning regarding socioscientific issues: A critical review of research. Journal of Research in Science Teaching, 41(5), 513-536.

Sadler, T. D. (2011). Socioscientific issues in science classrooms: Teaching, learning and research (T. D. Sadler $E d$.). New York: Springer.

Sadler, T. D., Amirshokoohi, A., Kazempour, M., \& Allspaw, K. M. (2006). Socioscience and ethics in science classrooms: Teacher perspectives and strategies. Journal of Research in Science Teaching, 43, 353-376.

Sadler, T. D., Barab, S. A., \& Scott, B. (2007). What do students gain by engaging in socioscientific inquiry? Research in Science Education, 37(4), 371-391.

Sadler, T. D., Chambers, F. W., \& Zeidler, D. L. (2004). Student conceptualizations of the nature of science in response to a socioscientific issue. International Journal of Science Education, 26(4), 387-409.

Sadler, T. D., Foulk, J. A., \& Friedrichsen, P. J. (2017). Evolution of a model for socio-scientific issue teaching and learning. International Journal of Education in Mathematics, Science and Technology, 5(2), $75-87$.

Saunders, K. J., \& Rennie, L. (2013). A pedagogical model for ethical inquiry into socioscientific issues in science. Research in Science Education, 43(1), 1-22.

Simon, S., \& Amos, R. (2011). Decision making and use of evidence in a socio-scientific problem on air quality. In T. D. Sadler (Ed.), Socio-scientific issues in the classroom (Vol. 39, pp. 167-192). New York: Springer.

Smith, R. A., M'ikanatha, N. M., \& Read, A. F. (2015). Antibiotic resistance: A primer and call to action. Health Communication, 30(3), 309-314.

Stolz, M., Witteck, T., Marks, R., \& Eilks, I. (2013). Reflecting socio-scientific issues for science education coming from the case of curriculum development on doping in chemistry education. Eurasian Journal of Mathematics, Science and Technology Education, 9(4), 361-370. 
Strauss, A., \& Corbin, J. (1998). Basics of qualitative research: Grounded theory procedures and techniques (2nd ed.). Thousand Oaks: SAGE Publications.

Strauss, A., \& Corbin, J. (1994). Grounded theory methodology: An overview. In N. K. Denzin \& Y. S. Lincoln (Eds.), Handbook of qualitative research (pp. 273-285). Thousand Oaks: SAGE Publications.

Stuckey, M., Hofstein, A., Mamlok-Naaman, R., \& Eilks, I. (2013). The meaning of 'relevance' in science education and its implications for the science curriculum. Studies in Science Education, 49(1), 1-34.

Tidemand, S., \& Nielsen, J. A. (2017). The role of socioscientific issues in biology teaching: From the perspective of teachers. International Journal of Science Education, 39(1), 44-61.

Torp, L., \& Sage, S. (1998). Problems as possibilities: Problem-based learning for K-12 education. Alexandria: Association for Supervision and Curriculum Development.

U.S. Census Bureau. (2016). Defining rural at the U.S. Census Bureau. ACSGEO-1. Washington, DC.

Vallerand, R. J. (2008). On the psychology of passion: In search of what makes people's lives most worth living. Canadian Psychology/Psychologie Canadienne, 49(1), 1-13.

Van Aalsvoort, J. (2004). Logical positivism as a tool to analyse the problem of chemistry's lack of relevance in secondary school chemical education. International Journal of Science Education, 26(9), 1151-1168.

Vangrieken, K., Dochy, F., Raes, E., \& Kyndt, E. (2015). Teacher collaboration: A systematic.review. Educational Research Review, 15, 17-40.

Voogt, J., Westbroek, H., Handelzalts, A., Walraven, A., McKenney, S., Pieters, J., \& de Vries, B. (2011). Teacher learning in collaborative curriculum design. Teaching and Teacher Education, 27(8), 1235-1244.

Voogt, J., McKenney, S., Janssen, F., Berry, A., Kicken, W., \& Coenders, F. (2012). A framework for studying teacher learning by design. Paper presentation at the teachers as designers of technology enhanced learning pre-conference workshop in conjunction with the ISLS annual meeting. Sydney.

Wallace, C. S., \& Priestley, M. R. (2016). Secondary science teachers as curriculum makers: Mapping and designing Scotland's new curriculum for excellence. Journal of Research in Science Teaching, 54(3), 324 349.

Wheeldon, J., \& Faubert, J. (2009). Framing experience: Concept maps, mind maps, and data collection in qualitative research. International Journal of Qualitative Methods, 8(3), 68-83.

Zangori, L., Peel, A., Kinslow, A., Friedrichsen, P., \& Sadler, T. D. (2017). Student development of model-based reasoning about carbon cycling and climate change in a socio-scientific issues unit. Journal of Research in Science Teaching, 54(10), 1249-1273.

Zeidler, D. L. (2014). Socioscientific issues as a curriculum emphasis: Theory, research and practice. In S. K. Abell \& N. G. Lederman (Eds.), Handbook of research on science education (pp. 697-726). New York: Routledge.

Zeidler, D. L., \& Kahn, S. (2014). It's debatable!: Using socioscientific issues to develop scientific literacy K-12. Arlington: NSTA Press.

Zeidler, D. L., Herman, B. C., Ruzek, M., Linder, A., \& Lin, S.-S. (2013). Cross-cultural epistemological orientations to socioscientific issues. Journal of Research in Science Teaching, 50(3), 251-283.

Zeidler, D. L., \& Sadler, T. D. (2008). The role of moral reasoning in argumentation: Conscience, character and care. In S. Erduran \& M. P. Jiménez-Aleixandre (Eds.), Argumentation in science education: Perspectives from classroom-based research. New York: Springer.

Zeidler, D. L., Walker, K. A., Ackett, W. A., \& Simmons, M. L. (2002). Tangled up in views: Beliefs in the nature of science and responses to socioscientific dilemmas. Science Education, 86(3), 343-367.

Zohar, A., \& Nemet, F. (2002). Fostering students' knowledge and argumentation skills through dilemmas in human genetics. Journal of Research in Science Teaching, 39(1), 35-62.

Publisher's Note Springer Nature remains neutral with regard to jurisdictional claims in published maps and institutional affiliations. 